\title{
To Know or Better Not to:
}

\section{Agnotology and the Social Construction of Ignorance in Commercially Driven Research}

\author{
Manuela Fernández Pinto \\ Departamento de Filosofía, Universidad de los Andes, Colombia / m.fernandezp@uniandes.edu.co \\ Academy of Finland Centre of Excellence in the Philosophy of the Social Sciences, University of Helsinki, \\ Finland.
}

\begin{abstract}
With an innovative perspective on the social character of ignorance production, agnotology has been a fruitful approach for understanding the social and epistemological consequences of the interaction between industry and scientific research. In this paper, I argue that agnotology, or the study of ignorance, contributes to a better understanding of commercially driven research and its societal impact, showing the ways in which industrial interests have reshaped the epistemic aims of traditional scientific practices, turning them into mechanisms of ignorance production. To do so, l examine some of the main contributions to agnotology and provide a taxonomy of practices of ignorance construction common in commercially driven research today. In particular, I present the tobacco industry's campaign against the health hazards of smoking as a paradigmatic case of ignorance production, identifying five central strategies. I then argue that the same strategies have been used in three other cases — global warming, pharmaceuticals, and the 2008 financial crisis.
\end{abstract}

Keywords: agnotology, commercially driven science, social construction of ignorance.

\section{Introduction}

Through the $20^{\text {th }}$ century, the social organization of scientific research had radical transformations, from big in-house corporate labs fueled by major U.S. corporations, such as DuPont and General Electrics, to military funded projects for national defense during the Cold War, to new forms of private research in the global market, where outsourcing and off-shoring practices have prevailed (Mirowski and Sent, 2008). In particular, a general concern with a loss of U.S. competitiveness in the global market during the late 1970s and early
1980 s, led to major changes in the organization of research and development (R\&D) in the U.S. (Dertouzos, 1989: 306; Tyson, 1992: 291; Hunt, 1999: 19; Hart, 2001: 930; Coriat and Orsi, 2002: 1493; Mirowski, 2011: 115). Accordingly, with the end of the Cold War came the transition towards a new regime of science organization that has reshaped the role of science in liberal democracy (Slaughter and Rhoades, 2004; Davies et al., 2006; Fischer, 2009; Lave et al., 2010). 
The weakened intellectual property legislation proper of the Cold War was strengthened to accommodate the new R\&D commercial framework. A series of legislative Acts, transformed the connection between public and private research, allowing commercial profiting of publicly funded research (Barben, 2007: 62). The Bayh-Dole Act, for instance, famously granted property rights to universities over federally funded research, allowing them to profit from commercially driven research: "The act enabled universities to enter the marketplace and to profit directly when universities held equity positions in companies built around the intellectual property of their faculty as well as to profit indirectly when universities licensed intellectual property to private sector firms" (Slaughter and Rhoades, 1996: 318).

Changes in the corporate and university models meant changes in the organization of scientific research as well - most significantly, the in-house research lab was replaced through outsourcing R\&D - leading to the consolidation of a new regime of science organization with a new liaison between the industrial and the academic sectors (Mirowski, 2011: 94). Hans Radder (2010: 4) characterizes this ongoing commercialization of academic research as "the pursuit of profit by academic institutions through selling the expertise of their researchers and the results of their inquiries." As one would expect, the industrial influence in academic research has become a growing concern among science scholars, who have warned us against some of the possible consequences of commercially driven scientific inquiry (Greenberg, 2001, 2007; Bok, 2003; Slaughter and Rhoades, 2004; Wise, 2006; Resnik, 2007; Radder, 2010).

With an innovative perspective on the social character of ignorance production, agnotology, or the study of ignorance, has been a fruitful approach for understanding the social and epistemological consequences of the interaction between industry and academic research. ${ }^{1}$ Agnotology introduces a new perspective to the studies of science, one in which the social construction of ignorance becomes relevant for understanding scientific practice today. In particular, agnotological studies have uncovered the ways in which different mechanisms and practices, traditionally tied to knowledge production, have been reshaped and rechanneled to favor industry friendly outcomes, leading in many occasions to increasing ignorance among policy makers and the public at large. In this paper, I aim to show that the agnotological perspective contributes to a better understanding of commercially driven scientific research and its societal impact, showing the ways in which industrial interests have reshaped the epistemic aims of traditional scientific practices, turning them into mechanisms of ignorance production. To do so, I examine some of the main contributions to agnotology and provide a taxonomy of practices of ignorance construction common in commercially driven research today. In particular, I present the tobacco industry's campaign against the health hazards of smoking as a paradigmatic case of agnogenesis, i.e., of ignorance production, identifying five central strategies. I then argue that the same strategies have been used in three other cases - global warming, pharmaceuticals, and the 2008 financial crisis. To conclude, I summarize some of the advantages of using the agnotological perspective to understand commercially driven science as well as possible limitations of the approach.

\section{The social construction of ignorance}

Agnotology's main contribution to the social studies of science is its understanding of ignorance as a social construction. This differs from the traditional conception of ignorance as a natural vacuum:

\footnotetext{
We need to think about the conscious, unconscious, and structural productions of ignorance, its diverse causes and conformations, whether brought about by neglect, forgetfulness, myopia, extinction, secrecy, or suppression. The point is to question the naturalness of ignorance, its causes and its distribution. (Proctor, 2008: 3)
}

Accordingly, Proctor (2008: 3) distinguishes three kinds of ignorance. In the traditional sense, ignorance is understood as native state: A vacuum or void that needs to be replaced with knowledge. In a second sense, ignorance can be a passive construct or lost realm. This is the type of ignorance 
that grows from the social conditions in which science is made, including science's political geography (who is a scientist and why, and why science is done in some places rather than others) and the selection of certain lines of research over others. In this sense, ignorance emerges from the combination of decisions, circumstances and accidents that surround practices of knowledge production. Finally, ignorance can also be an active construct or strategic ploy: It can be deliberately made and maintained to fulfill the interests of certain people. In this sense, ignorance becomes a manufactured product, instead of being a natural or accidental result (Proctor, 2008: 6).

The study of the social construction of ignorance has two central characteristics (Fernández Pinto, 2015: 295). First, it is constructivist - it focuses on the manufactured character of ignorance as a phenomenon that needs to be studied, explained, and dealt with, especially, but not particularly, in scientific practice today. Second, agnotology in this sense is social - it is not concerned with the individual knower, but with the social circumstances that encourage the production of ignorance. The agnotological perspective emphasizes that a better understanding of the mechanisms through which ignorance is socially created and maintained would lead us to a more accurate understanding of the mechanisms of knowledge production.

Although the project of agnotology is not restricted to studies of commercially driven science - see, for example, the growing research on government secrecy (Galison, 2008; Balmer, 2012; Rappert, 2012; Kuchinskaya, 2014) — this has certainly been an important area for agnotology. The work of historian of science Robert Proctor $(1988,1995,1999,2012)$ on the tobacco industry's support of cancer research has been central to documenting the mechanisms of ignorance production in industry-funded science, as has been Oreskes and Conway's (2010) work on climate change and Michaels's (2008) account of the chemical industry. In addition, agnotological studies in the history of Big Pharma (NikKhah, 2014) and the history of the 2008 economic crisis (Mirowski, 2013; Mirowski and Nik-Khah, 2013) show further contributions in this respect. By synthesizing the main practices of ignorance construction and showing how their traditional epistemic purposes have been reshaped, this paper contributes to a better understanding of the import of commercial interests on scientific research today.

\section{The tobacco strategy}

The paradigmatic case of agnogenesis in the $20^{\text {th }}$ century is the U.S. tobacco industry's denial of the health hazards of smoking. ${ }^{2}$ The campaign began in 1953, when Ernest L. Wynder and his colleagues at the Sloan-Kettering Institute demonstrated that tobacco tars on the skin of mice caused fatal cancer (Wynder et al., 1953) and their findings were published in major journals and magazines in the U.S. On December $15^{\text {th }}$, the presidents of four major tobacco companies (American Tobacco, Benson and Hedges, Philip Morris and U.S. Tobacco) met with John Hill, founder and CEO of the famous public relations firm Hill \& Knowlton $(\mathrm{H} \& \mathrm{~K})$. This was the launching point of the tobacco industry's denial campaign, in which the U.S. tobacco industry together with $\mathrm{H} \& \mathrm{~K}$ would design and execute a strategy to counter scientific findings against tobacco smoking. Oreskes and Conway (2010: 6) call it the tobacco strategy: "Its target was science, and so it relied heavily on scientists - with guidance from industry lawyers and public relations experts - willing to hold the rifle and pull the trigger"; a strategy that has been widely acknowledged by the main scholars working on agnotology (Brandt, 2012; McGarity and Wagner, 2008; Michaels, 2008: 3-11; Mirowski and Nik-Khah, 2013: 282; Oreskes and Conway, 2010: 14-24; Proctor, 1995: 125-30; 2012: 22, 290-92). ${ }^{3}$

The mechanisms implemented by the tobacco industry to deceive the North American public and to perpetuate doubt about the health hazards of tobacco show that agnogenesis is a social and institutional phenomenon that has required the restructuring of many industry and academic settings. In particular, the tobacco strategy entailed the reshaping and rechanneling of different mechanisms and practices traditionally tied to knowledge production, with the aim of achieving new industrial goals.

I focus here on five core strategies or mechanisms fundamental to the tobacco strategy: (1) 
The emphasis on scientific uncertainty, (2) the support of friendly research, (3) the recruitment of distinguished scientists, (4) the creation of an echo chamber effect, and (5) the attack to unfavorable scientific research. Notice that these are all practices traditionally tied to the process of knowledge production - scientists know that their results are uncertain, research centers support research that contributes to their goals, research teams aim at recruiting distinguished scientists, scientists want to disseminate their research results widely, and scientific research is hold to high standards of criticism - but in this case they have been reshaped or rechanneled to fulfill the industry's purposes. In what follows, I examine each of these mechanism and highlight how the tobacco industry transformed its epistemic purposes to achieve its commercial aims, turning these mechanisms into practices of ignorance production.

\section{Emphasize the uncertainty}

Every scientist is familiar with the uncertain character of scientific knowledge. As David Michaels (2008: 165) claims: "Absolute certainty in science is rarely an option; uncertainty is the norm, not the exception; and scientists base their judgments on the weight of the evidence because in many instances they have no other choice. Uncertainty does not mean the science is flawed". And while uncertainty does not mean that the science is flawed, it does not play well in the policy process, where the more conclusive a study or an expert opinion is, the more useful it is for regulatory advice. Similarly, uncertainty also contravenes the public understanding of science, according to which research provides conclusive results.

For that reason, Hill's first strategic move was not a direct attack against the scientific findings that were threatening the tobacco industry, but to exploit the inherent skepticism proper of scientific research (Brandt, 2012: 64): The tobacco industry would endorse the scientific ethos by claiming that more and better research into the causes of cancer was needed. Fostering the concept of scientific uncertainty and creating doubt about the reliability and accuracy of unfriendly scientific results became the industry's leading tactic to oppose the science connecting smoking to lung cancer (McGarity and Wagner, 2008; McGoey, 2009; Michaels, 2008; Oreskes and Conway, 2010; Proctor, 1995, 2012; Smithson, 1989). As the famous 1969 Brown \& Williamson memo stated, "Doubt is our product, since it is the best means of competing with the 'body of fact' that exists in the mind of the general public" (quoted in Oreskes and Conway, 2010; Mirowski, 2012; Proctor, 2012).

As Oreskes and Conway (2010) explain, thanks to the popular idea that legitimate scientific claims are certain, uncertainty can be easily manipulated to create and sustain public policy debates. But, of course, scientists and science scholars know that certainty is an untenable ideal, and that science seeks high probabilities or best available knowledge: "History shows us clearly that science does not provide certainty. It does not provide proof. It only provides the consensus of experts, based on the organized accumulation and scrutiny of evidence" (Oreskes and Conway, 2010: 267-268). Taking advantage of this gap between the popular understanding of science and the actual status of scientific knowledge, the tobacco industry rechanneled the traditional notion of scientific uncertainty to foster ignorance instead of knowledge.

\section{Support friendly research}

In order to increase control on scientific research connected to tobacco smoking, U.S. tobacco companies united their efforts in the creation of a research council, initially named the Tobacco Industry Research Committee (TIRC) - later the Council for Tobacco Research (CTR). H\&K made a big splash about the creation of the TIRC with the publication of an advertisement, later known as the "frank statement," in more than 400 newspapers across the country (Brandt, 2012: 66). In the advertisement the industry acknowledged the importance of the health hazard claims made against tobacco smoking and made a public promise to support further research on the issue, although emphasizing that cigarettes had not been proved to cause health problems.

The TIRC/CTR was funded by the tobacco companies to control their public image, through a close relation with $\mathrm{H} \& \mathrm{~K}$. In fact, more than half of the Council's first year budget went to H\&K (Proctor, 2012: 267). The TIRC/CTR funded a 
massive amount of scientific research through research grants, which were given to scientific experts in major universities and research institutions. In this sense, the TIRC/CTR was not conceived to support fraudulent research, but to use "good" research as a distraction. The agnotological move was a selection bias: "The bias stems from the fact that the CTR really wasn't designed to explore whether, how, or to what extent smoking causes illness... Grants were rarely given to anyone who knew much about tobacco and health" (Proctor, 2012: 269). When the first TIRC grants were announced, Alton Ochsner, a wellknown thoracic surgeon, immediately noticed the problem:

\footnotetext{
Of course, the critical areas of investigation, as every research scientist knows, have to do with the problem of how to make smoking a less lethal agent in lung cancer incidence and a less deadly killer in heart disease. Yet it is precisely these areas that apparently have been declared out of bounds for the industry's research committee. (Ochsner, 1954: 72)
}

TIRC grants funded research on heredity, infection, nutrition, hormones, nervous tension, and environmental factors, emphasizing that all of these fields of research were important for understanding the causal mechanisms of cancer and heart disease (Little, 1959: 2). Tobacco smoking was considered only as one of many environmental factors that could contribute to such health problems, downplaying its importance for future research. Even though the TIRC/CTR had a science advisory board, all grant applications were first filtered by CTR lawyers for litigation purposes (Barnes et al., 1995: 250). It was this bias at the macro-level that the TIRC/CTR together with $\mathrm{H} \& \mathrm{~K}$ put in place to manipulate science and create ignorance.

The strategy was repeated by the tobacco industry later on during the controversy regarding environmental tobacco smoke (ETS), or secondhand smoke, and its connection to lung cancer. In 1987, the industry founded the Center for Indoor Air Research (CIAR) with the aim of producing friendly research (Drope and Chapman, 2001: 590). Like the CTR, the CIAR identified projects that seemed promising to the tobacco industry's interests and funded them through different grants. Research organization such as the CTR and the CIAR worked as intermediaries between the tobacco companies and "independent" scientists. In addition, the tobacco industry also provided funding for medical research projects in universities, created scholarships to finance medical students, and established relationships with members of some of the most important associations on health issues, such as the National Cancer Institute and the American Health Association (Parascandola, 2005; Oreskes and Conway, 2010; Proctor, 2012).

While the support of friendly research through financial and institutional arrangements is a common strategy to encourage scientific research in certain target areas - think for example about the directed efforts to find a cure for HIV, breast cancer, Alzheimer's disease, etc. - the tobacco industry reshaped this common strategy of knowledge production to appear interested in scientific progress, while obstructing the actual achievement of scientific knowledge, transforming in this way the support of friendly research into a mechanism of ignorance production.

\section{Find scientists to support your cause}

Along with the creation of research organizations came the recruitment of distinguished scientists, whose authority and academic connections would help the industry's goal of fostering uncertainty about scientific claims. Accordingly, the tobacco industry hired Dr. Clarence Cook Little as first scientific director of the TIRC. Little, a renowned biologist, geneticist, and eugenicist, was carefully chosen for his strong skepticism towards the epidemiological work connecting tobacco smoking with lung cancer. As a geneticist, he favored the idea that cancer had genetic origins and thus conducted and supported basic research regarding the mechanisms of cancer with animal testing, without ever making the connection to humans (Brandt, 2012: 66). Little became a key spokesperson for the tobacco industry's campaign against the health hazards of smoking, focusing on misleading lines of research, and increasing the confusion and misinformation by introducing scientific "noise" into the public discourse. 
Another key example of the industry's recruitment of scientists as allies was the employment of Frederick Seitz as director of R. J. Reynolds' research program. Seitz was one of the most distinguished scientists in North America. A former student of Eugene Wigner, he became science advisor to NATO in 1959, then president of the National Academy of Scientists (1962 -1969), and in 1968 president of the Rockefeller University, one of the leading institutions in biomedical science in the country (Oreskes and Conway, 2010: 25-26). After retiring in 1979, he went to work for R. J. Reynolds, which gained the credentials of one of the most respected scientists in the country. Just as Little, Seitz favored the idea that cancer had genetic causes, and explicitly rejected the idea that emphysema could be caused by environmental factors such as smoking. His scientific credentials made Seitz a key figure for the tobacco strategy. He would publicly oppose scientific research on the environmental causes of cancer and directly attack scientists conducting this type of research.

The tobacco industry also looked for allies to counter the scientific findings that supported the hazards of ETS with the creation of an international program of scientific consultants. The ETS Consultants Program, as it was called, sought scientific experts worldwide to keep the "controversy" regarding ETS alive, and delay regulatory measures. In order to avoid the direct connection between the industry and the scientists, the industry hired a law firm, Covington \& Burling, to conduct the screening, recruitment, and training of experts (Muggli et al., 2003: 306). Scientific consultants were asked to testify before Congress, to publish articles in scientific journals, to attend ETS conferences, and to submit letters to editors in response to adverse articles (Drope and Chapman, 2001: 590). Given the fact that the ETS Consultants Program was international, the program rendered "foreign" experts for the tobacco industry, as well as a web of regional contacts to campaign against regulatory efforts worldwide.

The tobacco industry took advantage of a strategy normally used to encourage the production of scientific knowledge, i.e., to recruit wellknown experts on the field. The strategy, of course, is built on the presupposition that renowned scientists will contribute their particular expertise and experience in the field to buttress the process of knowledge acquisition. In this case, however, the tobacco industry recruited the scientists as a PR strategy to capitalize on their scientific credentials. That is, to support their own industrial interests with the credibility and recognition of these experts. In fact, the most renowned experts, such as Little or Seitz, occupied administrative positions and not research positions. Thus, the recruitment of renowned scientists was no longer guided by the traditional epistemic aims, but instead followed other commercial aims.

\section{Spread the word (or the creation of an "echo chamber effect")}

Proctor (1995) has emphasized the central role that PR firms play in the development of practices of ignorance construction. In particular, he calls attention to the fact that commercially driven science has become an instrument of PR, the tobacco industry's close relation with H\&K being a clear example of this. The creation of research organizations and the support of scientific experts were crucial to Hill's strategy precisely because they sustained a full-blown advertisement campaign in the media to maintain cigarette consumption.

As one would expect, manipulating media coverage also became an important tool for the tobacco industry in the fight against regulation. Appealing to journalistic balance under the "fairness doctrine," which required broadcasters to include opposing views when treating controversial issues of public importance, industry lawyers demanded equal time for both sides of the debate. Every time scientific research was invoked to claim that smoking caused lung cancer, industry lawyers contacted the relevant venue and provided a list of "independent" scientific experts that would challenge the research. Such an appeal for "balance" and "objectivity" led the general public to believe that experts had not arrived yet at a scientific consensus regarding the link between smoking (and later second hand smoke) and lung cancer. In Oreskes and Conway's (2010: 19) terms: "Balance was interpreted, it seems, as giving equal weight to both sides, rather than giving accurate weight to both sides". 
Much of the success that the tobacco industry had buying time and space in mass media was due to the journalistic commitment to telling both sides of the story. The TIRC/CTR exploited precisely this feature of the journalistic ethos to keep the public debate alive. Given that the strategy of appealing to balance was used, and continues to be used, in several other scientific controversies (see McGarity and Wagner, 2008: 224-26), it is now obvious that a fundamental conflict between the scientific and the journalistic ethos has been exploited as a strategy of ignorance construction (Antilla, 2005; Boykoff and Boykoff, 2004, 2007; Freudenburg and Musselli, 2010).

In addition to public media, the tobacco industry also made important efforts to support the dissemination of industry-friendly research within the scientific community. Part of this strategy was the creation and distribution of nonpeer-reviewed journals and pamphlets, such as the Tobacco and Health Report, a monthly newsletter published by the TIRC (Proctor, 2008: 14-15). Another example was the funding and organization of symposiums, which allowed the industry not only to control the amount of industry friendly research presented, but also to increase industry-friendly publications through symposia proceedings. In this way, the tobacco industry circumvented peer review standards in publication, without compromising its façade of research supporter. Symposia proceedings are after all part of the scientific process through which a researcher communicates her work to her peers, even though the research is not really qualified as finished until it gets published in a peer-reviewed journal. The tobacco industry took advantage of this fact, and frequently used symposia proceedings as expert references in the "controversy" regarding ETS. Symposium articles, however, were more likely to agree with the tobacco industry's views on ETS ( $46 \%$ vs. $20 \%$ ), less likely to endorse the risks of ETS ( $22 \%$ vs. $49 \%$ ), and more likely to be written by scientists affiliated with the industry (35\% vs. $6 \%$ ), than peer-reviewed articles (Bero et al., 1994: 612).

Dissemination of results within the scientific community is a priority. In fact, scientists compete to publish results first, thus speeding up the process of knowledge production. The tobacco industry transformed this common scientific practice as well as its epistemic aims. Instead of emphasizing the prompt publication of reliable research results, the quality of which is assured by the peer review process, the industry reshaped publication mechanisms, emphasizing the breadth of the dissemination and undermining its epistemic quality.

\section{Attack unfriendly research and researchers}

Finally, the tobacco strategy also included the attack to scientific research and researchers, who were presenting unfriendly results for the industry. In some cases, the industry triggered personal attacks on scientists with good scientific credentials, accusing them of not following scientific standards or claiming that they were politicizing research. Salient here is the attack against Takeshi Hirayama and his research on the health hazards of second hand smoke (Hirayama, 1981). The industry launched a campaign to undermine Hiramaya's reputation, accusing him of committing crucial statistical errors (Oreskes and Conway, 2010: 137-143; also mentioned in Michaels, 2008: 86-7 and Proctor, 2012: 190), despite the fact that tobacco industry's researchers had found Hirayama's results to be correct (Ong and Glantz, 2000).

Part of the strategy was also to oppose government funded research. For instance, when the EPA released the report Respiratory Health Effects of Passive Smoking (1992), in which chronic disease and death was attributed to secondhand smoke, the industry (through Fred Singer) accused the EPA of doing "junk science," and holding positions that were not supported by scientific findings (Oreskes and Conway, 2010: 140-42). The "junk science" movement allowed the tobacco industry to accuse perfectly legitimate science of being "junk," while promoting the idea that their own research was "sound science," uncorrupted by particular political interests.

The main aim of the "junk science" rhetoric was to weaken academics and their research in the mass media by "promoting the idea that there is a surfeit of dodgy academic science corrupting the journals and airwaves, fostering the impression that every concerned citizen must gird themselves to be wary of corruption in the vast archive of scientific thought" (Mirowski, 2011: 297). Oreskes 
and Conway (2010: 232) as well as Michaels (2008: xi) trace the "junk science" movement back to the tobacco industry's attempt to discredit scientific research that they didn't like. They portray it as an Orwellian crusade to undermine real science as "junk", and replace it with "sound" industry friendly research.

The attack to unfriendly research and researchers is probably the clearest case of the industry driven transformation of scientific research practices, undermining the production of knowledge. Of course scientific research results undergo a critical process in which other scientists are encouraged to object to the results, to find methodological flaws, to question the reliability of the data, etc. Within the scientific community it is also legitimate to attack other scientists for doing "bad" science, i.e., committing scientific fraud, not following the appropriate standards, being biased, etc. Both of these are mechanisms for keeping in check the epistemic quality of the research. The tobacco industry rechanneled them, however, to fulfill a very different aim, i.e., to undermine scientific research and researchers that were problematic for the industry's commercial interests, thus obstructing knowledge and creating ignorance.

The tobacco strategy was initially designed and developed by $\mathrm{H} \& \mathrm{~K}$ as a PR campaign for U.S. tobacco companies, implementing at least five core practices: (1) The emphasis on scientific uncertainty, (2) the support of friendly research, (3) the recruitment of distinguished scientists, (4) the creation of an echo chamber effect, and (5) the attack to unfavorable scientific research. In each case, the tobacco industry transformed these traditional practices of knowledge production to fulfill its commercial interests. But in doing so, the industry also compromised the epistemic goals of these mechanisms, turning them into ignorance productive strategies.

\section{The tobacco strategy meets climate science, pharmaceuticals, and economics}

The tobacco strategy proved to be highly successful. The industry did not lose any court cases till the 1990s and the FDA was not able to regulate tobacco as an addictive drug until 2009 (Oreskes and Conway, 2010: 33). Moreover, the tobacco strategy has become a model of agnogenesis for countering scientific knowledge in other fields. In this section, I show that the same mechanisms have been similarly repurposed in three other cases: global warming, pharmaceuticals, and the 2008 financial crisis.

\section{Global Warming}

Global warming is one of the central case studies in Oreskes and Conway's Merchants of Doubt (2010). Despite the Intergovernmental Panel on Climate Change's (IPCC) endorsement of the anthropogenic climate change hypothesis by 1995 and its ratification by the scientific community, the American public remained skeptical about it (2010: 169). Noticing that this was at the peak of North American public awareness of climate change - the short period between 2006 and 2007 in which the Republican anti-environmental voting decreased, the Democrats were actively engaged in the fight against climate change, and Al Gore's documentary An Inconvenient Truth (2006) received two Oscars (Brulle et al., 2012) — Oreskes and Conway ask why the public did not endorse the scientific consensus on anthropogenic climate change.

To a great extent, the gap between the scientific community's and the public's stances regarding climate change responds to a denial campaign following the tobacco strategy. McCright and Dunlap (2000, 2003, 2010, and 2011) trace this campaign to a conservative movement led by major think tanks in the U.S., such as the American Enterprise Institute, the Cato Institute, the Heritage Foundation, and the Marshall Institute (2003: 355). Oreskes and Conway (2010), on the other hand, are more concerned with the scientists who put their scientific expertise and credentials to attack the scientific community and support private interests. But there is no doubt that the major financial support for this campaign has come from the U.S. fossil fuel industry, especially ExxonMobil (Gelbspan, 1997: 46; Mooney, 2005; Michaels, 2008: 56; Dunlap and McCright, 2010: 245; Oreskes and Conway, 2010: 246; Perrow, 2010: 62; Weber and Stern, 2011: 321). The Union of Concerned Scientists (2007) has documented the funding of several think tanks by ExxonMobil, and Greenpeace (2010) has done the same for the 
case of Koch Industries. Moreover, Greenpeace has also developed an online tool to track ExxonMobil's funding to specific think tanks and then to specific scientists. ${ }^{4}$

The fossil fuel industry has followed the path of the tobacco industry in designing and developing a PR campaign to counter scientific consensus on global warming. Let me mention here some of the most salient similarities. First, they are both denial campaigns that foster scientific uncertainty and exploit scientific skepticism, undermining the epistemic value of scientific uncertainty. Just as the tobacco industry decided to attack science with more science, so have climate change skeptics. Their main strategy has been to create doubt and uncertainty regarding the science behind climate change, and they have succeeded by implementing some of the same strategies to confuse the North American public (Dunlap and McCright, 2010). For instance, take Frank Luntz's memo to the Republican Party: "Should the public come to believe that the scientific issues are settled, their views about global warming will change accordingly. Therefore, you need to continue to make the lack of scientific certainty a primary issue in the debate" (Luntz, 2003: 137; quoted in Michaels, 2008: xi). ${ }^{5}$

The fossil fuel industry, however, faced the challenge of global warming during a different time period than the tobacco industry. Research on the health hazards of smoking became public in the U.S. in 1953, while the first reports on scientific consensus on climate change came in the early 1980s (e.g., National Research Council, 1983). This might explain why the fossil fuel industry has not only used research organizations, such as the American Petroleum Institute, to channel its funding of scientific research, but has also supported several think tanks, which have become central to the anti-environmentalist counter movement of the American right, especially after the 1992 UN Earth Summit in Rio de Janeiro (Austin, 2002; Jacques et al., 2008).

Following the tobacco strategy, some think tanks have made a huge effort to recruit renowned scientists that are climate change skeptics. As Oreskes and Conway (2010) have documented, William Nierenberg has been crucial to the campaign against global warming.
Former physicist of the Manhattan Project and former director of the Scripps Institution of Oceanography, Nierenberg was appointed chair of the Carbon Dioxide Assessment Committee to undertake a comprehensive study of $\mathrm{CO}_{2}$ and climate, which later became the 1983 NAS report. A team of climate scientists and, surprisingly, two economists, were put together to evaluate the state of the Earth's climate.

In the end, instead of producing a joint report based on consensus, the 1983 NAS report, Changing Climate: Report of the Carbon Dioxide Assessment Committee, contained two contradictory views regarding climate change: "five chapters detailing the likelihood of anthropogenic climate change written by natural scientists, and two chapters on emissions and climate impacts by economists - which presented very different impressions of the problem" (Oreskes and Conway, 2010: 177). The natural scientists concluded that global warming was a real problem and that preventive measures were needed. The economists, on the other hand, argued that the evidence was not conclusive, and that the government ought to fund more research before acting. Despite the contradictory views that appeared in the report, the summary sided with the minority's views. Surprisingly, the report became a central tool in certain governmental sectors to counteract environmental policy: "the Nierenberg report didn't go out with the morning trash. It was used by the White House to counter scientific work being done by the EPA" (Oreskes and Conway, 2010: 182). In fact, the report was used against almost every initiative seeking to control the emission of greenhouse gases.

The NAS report is just one of the many examples that Oreskes and Conway (2010) examine regarding global warming, where information was manipulated - it was hidden, distorted, presented with a deceptive emphasis, etc. - to create the idea that scientists had not yet achieved consensus about global warming. Moreover, the controversy was advocated by a small group of very distinguished scientists, which gave the impression that this was in fact a scientific controversy, with prominent scientists in both camps. In addition to Nierenberg, Robert Jastrow (astrophysicist, head of the Goddard 
Institute for Space Studies), Frederick Seitz (previously mentioned as a key player for the tobacco companies), and Fred Singer (rocket scientist, first director of the Nation Weather Satellite Service) also participated as science collaborators.

Just as the tobacco industry, climate change skeptics have also made several attacks to scientific research that goes against their interests. For instance, Oreskes and Conway (2010: 190-197) document the dubious attempt to coerce a convalescent Roger Revelle into collaborating with Fred Singer to publish a paper against his own scientific views.

In this way, industrial interests have reshaped and rechanneled mechanisms of knowledge production in the global warming case, such as the emphasis on scientific uncertainty, the recruitment of renowned scientists, the support of friendly research, and the attack to unfriendly research and researchers.

\section{Big Pharma}

The pharmaceutical industry learned quickly from the tobacco mongers. Edward Nik-Khah (2014) tracks the beginning of the pharmaceutical industry's application of the tobacco strategy to the 1971 Drugs conference at the University of Chicago. Financed by some of the major pharmaceutical corporations (such as Novartis, Merck, and Pfizer), and organized by faculty members of the Chicago School of Economics (Milton Friedman, Richard Posner, and George Stigler among them), the Drugs conference was a collective attempt of Big Pharma to oppose the 1962 Kefauver-Harris Amendments to the Federal Food, Drug, and Cosmetic Act, which allowed the FDA to exercise media control, establish standards for clinical trials, and demand appropriate efficacy proofs for new and marketed drugs. After the conference, the Center for Policy Studies published the volume Regulating New Drugs (Landau, 1973), a collection of the main contributing papers. The book's contributors opposed the 1962 Amendments and drug regulation more generally, showing a strong commitment to the neoliberal ideology of the Chicago School of Economics (Nik-Khah, 2014: 494). The resulting volume of the conference was well publicized, receiving the support of the wellknown neoliberal economist Milton Friedman in his Newsweek column, and of Alan Greenspan in the Objectivist Newsletter (Nik-Khah, 2014: 495).

Not long after the conference, the American Enterprise Institute (a major think tank with Friedman among its members) created the Center for Health Policy Research (CHPR). ${ }^{6}$ The CHPR brought together many of the participants of the Drugs conference, who united their efforts to organize further conferences, publish books and research studies, and distribute easily understandable pamphlets. In a similar vein and only two years later, Louis Lasagna, who also attended the 1971 conference, established the Center for the Study of Drug Development (CSDD). As Nik-Khah explains, the CSDD instituted a "policy of secrecy" to keep hidden its close collaboration with the University of Rochester, and later with Tufts. The CSDD collected data from pharmaceutical companies, put together studies on new drugs, and helped with publications, following articles through the peer review process, all while granting full confidentiality to pharmaceutical companies (Nik-Khah, 2014: 502).

The pharmaceutical industry not only exploited the resources of PR and academic ties in its favor, but also went further than the tobacco industry in controlling scientific research through the peer review system. While the tobacco industry emphasized the publication of pamphlets and symposiums proceedings, the pharmaceutical industry has created a way to spread friendly research through peer-reviewed journals. In "Ghosts in the Machine" (2009), Sergio Sismondo carefully describes the central aspects of "publication planning," which is nothing but the organized effort of pharmaceutical companies to obtain favorable scientific research through exercising a close control over every phase of the research process leading to publication - i.e., data collection from contract research organizations (CROs), ghostwriters, signatures from "independent" medical researchers, peer review process, and finally the creation of an echo chamber effect. Sismondo summarizes the process as follows:

Most sponsored clinical trial research is handled

by contract research organizations (CROs),

the data they produce is typically analyzed by pharmaceutical company statisticians, papers are written by medical writers, and the whole process 
is guided and shepherded through to publication by planners and planning teams... To gain the most commercial value from research, the papers publicizing it are written under the names of independent medical researchers... (Sismondo, 2009: 172)

This "ghost management" of research and the publication process has become central for the pharmaceutical industry. According to Sismondo (2009: 172), up to $40 \%$ of reports on clinical trials of new drugs are the result of some publication planning firm, making this practice a well-structured and organized form of commercially driven medical research. In this case, the pharmaceutical industry controls not only the lines of research pursued, but it actually intervenes, first in the research process, using its own statisticians to find favorable ways to present research results, and later in the publication process, through ghostwriting practices. The pharmaceutical industry is changing traditional methodological standards in medical drug trials with respect to experiment design, data gathering and interpretation, and results publication, which leads to questioning the implications of these changes for the production of scientific knowledge.

Publication planning however did not appear overnight. Big Pharma learned the lesson from the tobacco industry on how to create an "echo chamber effect" so that a single finding favorable to the industry could resonate as much and as loud as possible. But it also learned from its own experience to strengthen its practices of ignorance construction. Take for example the Vioxx scandal. Initially targeted for the treatment of arthritis, Vioxx had the advantage over other painkillers of not causing gastrointestinal complications. In 1999, Vioxx manufacturer Merck decided to conduct a major clinical trial in an attempt to prove Vioxx's superiority to Aleve. The findings were rather unfortunate for Merck: People taking Vioxx had four times the risk of suffering a heart attack than those taking Aleve (McGoey, 2009: 156; Michaels, 2008: 146). Refusing to accept these results, Merck's scientists decided to go with a much more favorable interpretation of the data. Instead of claiming that Vioxx increased heart failure, they favored the idea that Aleve helped reduce such risk. A rather unjustified move, from a scientific point of view, given that Aleve was not known to reduce heart failure, and Merck's interpretation made it much more effective than aspirin in this respect. In Doubt is their Product (2008), David Michaels explores the Vioxx controversy, and concludes:

\footnotetext{
I found it harder and harder to believe that this was merely a case of well-meaning scientists unintentionally misinterpreting the data... No drug has ever been shown to reduce heart attack risk by 80 percent. If the scientists honestly believed their claim, they should have lobbied the government to pour Aleve directly into the nation's water supply. (Michaels, 2008: 148)
}

Merck went on to defend this controversial interpretation of the data, displaying an array of ignorance constructive tactics such as threatening scientists who opposed it, and using constant PR to undermine the risks of heart failure from Vioxx in the media (Michaels, 2008: 147).

Linsey McGoey (2009) portrays the Vioxx scandal also as a case of unjustified fostering of uncertainty on Merck's part (another of the central components of the tobacco strategy). McGoey (2008: 158) highlights the manipulation of the concept of uncertainty in the industry's advantage: "By stressing the uncertainty of the facts surrounding the safety of drugs such as Vioxx, regulatory hesitations in removing the drug from the market seem prudent rather than negligent." And she concludes by stressing that this misuse of uncertainty further protects the concerned players, by making them many times immune to liability.

As Merck's Vioxx case illustrates, major pharmaceutical companies have followed closely the tobacco strategy. They have not only learned, but improved many of the tactics, pervading the peer review system in unprecedented ways (through 'ghost management' of publications), and creating new and better strategies for manipulating scientific data through a careful design of clinical trials to favor their drugs (Michaels, 2008: 149). But, in general, the pharmaceutical industry has followed the same strategies as the tobacco industry. It has fostered uncertainty regarding scientific research that is unfriendly to the industry (McGoey, 2009), it has created research organizations to oppose 
scientific consensus (such as the CHPR and the CSDD), using major think tanks (such as the American Enterprise Institute) to channel their funds, it has recruited distinguished scientists to use their scientific credentials in their favor, and it has used the media, the funding of conferences, and the publication of favorable research as a PR strategy to promote their views with the public and within the scientific community.

\section{The 2008 Economic Crisis}

In August 2012, the Justice Department closed the criminal investigation of Goldman Sachs regarding its role in the 2008 financial crisis. While the U.S. government failed to convict anyone for federal fraud, the public has remained deeply unsatisfied with the outcome. A 2012 editorial in the New York Times put it bluntly:

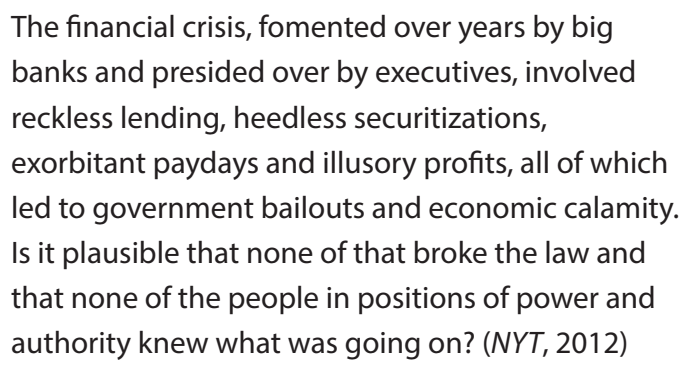

Even more striking has been the realization that economists were caught up by surprise, and seemed totally unprepared to explain what happened. As Paul Krugman (2009) explains, macroeconomists were divided "between those who insisted that free-market economies never go astray and those who believed that economies may stray now and then but that any major deviations from the path of prosperity could and would be corrected by the all-powerful Fed." And financial economists completely ruled out the possibility of a crisis by definition: they "came to believe that markets were inherently stable - indeed, that stocks and other assets were always priced just right" (Krugman, 2009).

In the aftermath of the crisis, part of the problem has been the lack of consensus within the economics profession to explain what really happened, and why it happened. Phil Mirowski (2013) presents an agnotological analysis of the 2008 financial crisis, uncovering some of the reasons there has not been a serious effort from the economics profession to explain the crisis in theoretical terms, which in turn has made any attempt at prosecution pointless. In particular, he argues that different strategies of ignorance production have been implemented in the aftermath of the crisis to confuse the American public and delay any serious interpretation of the event:

\footnotetext{
The most important part of the history of the crisis that has been neglected ... is that there have surfaced in the crisis some relatively systematic attempts to pump doubt and confusion into public discourse; in other words, some 'explanations' of manifestations of the crisis and its aftermath have been launched as trial balloons not expressly for purposes of further test and elaboration by sanctioned professional economists, but rather as calculated interventions in public discourse in order to buy time and frustrate any shared impressions of a few sharply delineated positions on a contentious issue. (Mirowski, 2013: 226)
}

In this sense, the financial collapse should not be interpreted as a mere lack of agreement among economists (i.e., as a legitimate scientific debate), but as a new case of agnogenesis, in which practices of ignorance construction have impeded the understanding of this economic phenomenon. I will focus on one of Mirowski's examples, i.e., the spreading of a mistaken explanation for the crisis, and the subsequent failure of the Federal Crisis Inquiry Commission.

The most popular right-wing account of the crisis reduces the financial collapse to a housing bubble, which grew uncontrolled thanks to an extension of loans to people who couldn't financially support them. This type of low-quality (subprime) loans became possible, so the story goes, after the Democrats passed the Community Reinvestment Act (CRA) in 1977. On the other end, the Government Sponsored Enterprises (GSEs) Fannie Mae (Federal National Mortgage Association) and Freddie Mac (Federal Home Loan Mortgage Corporation) facilitated the concession of mortgages to cover such loans. Thus, at the end, "the government had polluted the mortgage market, first causing the housing bubble, and then the subsequent collapse. It was all the fault of the government. Full stop" (Mirowski, 2013: 313). 
However, as some economists and reporters have pointed out, blaming the CRA together with Fannie and Freddie for the collapse is mistaken (Krugman, 2008; Goldstein and Hall, 2010; Min, 2011; Nocera, 2011). First, the CRA did not regulate the private firms in the subprime market (where the crisis started), and even the number of loans that fell under the CRA was small among the firms it did regulate; not to mention that the timing is somewhat off, after all the CRA was passed in 1977 (Mirowski, 2013: 316). Second, the GSEs had been actually losing shares in the subprime market since 2002, given that this market was primarily a privately run machine, and their own government guidelines limited the GSEs mobility in it (Mirowski, 2013: 317). Thus, neither the CRA nor the GSEs provided enough control of the subprime market to account for market failure. This is consistent with the Federal Reserve Board data, according to which "more than 84 percent of the subprime mortgages in 2006 were issued by private lending institutions" (Goldstein and Hall, 2010).

Why then did Fannie and Freddie become common targets in the aftermath of the financial crisis? Mirowski traces the way in which this hypothesis became the central cover up story for the political right and in particular for what he calls the "neoliberal thought collective." Here again the repurposing of traditional practices of knowledge production became central: Recruitment of wellknown economists, funding of research that supports the right-wing cause, the publication of a concrete story that favors private interests, and finally the creation of an echo chamber effect in popular media.

By creating an "echo chamber effect," the neoliberal thought collective was able to expand the Fannie and Freddie story from a few experts to the public at large. Mirowski documents how the hypothesis was first tried in August 2008 by Charles Calomiris (from the Cato Institute) and Peter Wallison (from the American Enterprise Institute) in the Wall Street Journal (Calomiris and Wallison, 2008). The two think tanks played a central role in spreading the hypothesis around, supporting it with numerical data, putting it in the blogosphere, and selling it through academic publications (e.g., in Raghuram Rajan's Fault Lines
(2010)). In particular, the AEI financed Edward Pinto's research on the financial crisis (Pinto, 2010). Pinto's study provided the numerical data to back up the idea that the CRA together with the GSEs were to blame for the crisis. For instance, Pinto (2010: 29) claimed that in 2008 over $70 \%$ of weak or high risk loans were owned or supported by GSEs or banks under the CTA.

The real power of this strategy was not seen until the Financial Crisis Inquiry Commission (FCIC) was set in place, early 2010. Created initially with the aim to "provide trenchant research and a communal teaching experience concerning the causes of the crisis" (Mirowski, 2013: 319), the FCIC failed to deliver a joint report. The official report was endorsed by a majority of six out of ten bi-partisan members, while the four remaining conservative members decided to express their disagreement in two dissenting appendices added to the official report: "Dissenting views by Keith Hennessey, Douglas Holtz-Eakin, and Bill Thomas" and "Dissenting views by Peter J. Wallison." In the official conclusion of the report, the FCIC explicitly discarded that Fannie and Freddie as primary causes of the crisis (FCIC, 2011: xxvi). Meanwhile in his dissenting remarks, Peter Wallison (fellow of the $\mathrm{AEI}$ ) endorsed the Fannie and Freddie story, blaming the U.S. government's housing policy for the crisis (FCIC, 2011: 444), and quoted Pinto's (2010) data as evidence for the lack of objectivity of the official report: "the Commission majority's report ignores hypotheses about the causes of the financial crisis that any objective investigation would have considered, while focusing solely on theories that have political currency but far less plausibility" (FCIC, 2011: 476). In the end the report was inconsistent. The majority's conclusions stated that GSEs were not to blame for the crisis, while the dissenters claimed the opposite. ${ }^{8}$

If Mirowski is correct, the neoliberal thought collective, using Wallison as key expert on the case, was able to twist a national effort (worth six million dollars) to investigate the origins of the financial collapse, spreading confusion and creating the idea that disagreement among experts in the commission probably entailed a true difficulty in determining the real causes of the crisis and who was responsible. Which takes us back to the beginning of this section on the 
economic crisis. The government couldn't find out whom to blame, it is now very unlikely that anyone will be prosecuted for the collapse, U.S. taxpayers' money was just wasted, and we still lack reliable knowledge about what happened. And, finally, notice again the similarities with the tobacco industry's reshaping of distinct practices traditionally involved in the process of knowledge production; in this case, support from key "experts," downplaying real scientific analysis of the crisis, and creating an "echo chamber effect" through publications.

\section{Conclusion}

The aim of his paper was to show that agnotology is a useful tool for better understanding the impact of the industrial interests that pervade science today. In particular, agnotological studies have uncovered the ways in which different mechanisms and practices, traditionally tied to knowledge production, have been reshaped and rechanneled to favor industry-friendly outcomes, turning them into mechanisms of ignorance production. Through an examination of the tobacco case, one can identify at least five of these mechanisms, where the epistemic purposes have been compromised: (1) The emphasis on scientific uncertainty, (2) the support of friendly research, (3) the recruitment of distinguished scientists, (4) the creation of an echo chamber effect, and (5) the attack to unfavorable scientific research. Moreover, the same mechanisms have been used to favor industrial interests, undermining at the same time the process of knowledge production in a variety of cases, such as climate science, pharmaceutical research, and economics.

Endorsing the agnotological perspective, however, also entails further challenges. Some have objected to the project, claiming that agnotology's treatment of ignorance is too ambiguous or too vague to constitute a legitimate area of inquiry. Indeed, agnotology aims to be as broad as epistemology, i.e., to study ignorance with the breadth and depth with which epistemology studies knowledge (Proctor, 2008: 1). Thus, agnotology would have in principle as many branches as epistemology: Formal, Bayesian, local, evolutionary, moral, feminist, naturalized, social, and so on. But many of these different possible approaches to the study of ignorance have not been explored yet, and accordingly they have not gained disciplinary recognition. Until then, agnotology will probably remain a vague field of study.

If one looks closer at particular cases though, one narrows the breadth of the agnotological study and works with a narrower understanding of ignorance that is less ambiguous. In the paper, for instance, I examine cases of ignorance as strategic ploy or active construction (Proctor, 2008: 3), in the context of commercially driven scientific research today, where particular mechanisms of ignorance production can be identified. In this case, ignorance is the product of the reshaping and rechanneling of traditional practices of knowledge production, whose epistemic purposes are transformed in the process of fulfilling industrial interests. It is in this shift of purposes from epistemic to industrial that the product of the practice changes as well, in this case, from knowledge to ignorance.

I do not wish to claim that all commercially driven research uses practices of ignorance production in the way just described or that government funded research is free from incurring in the same actions. My claim is the smaller one that commercially driven research has encouraged these types of practices, as industrial interests start driving scientific research. Hence, the connection I want to highlight here is a contingent one between industrially driven research today and the reshaping of what have been practices of knowledge production.

Another important challenge to agnotology is related to the normative character of the concept of ignorance. Just like knowledge, ignorance is normally used in normative terms. While knowledge is traditionally understood as positive, as justified true belief, perhaps with a specific type of communal approval, ignorance is understood as negative, as a state of non-knowledge. But just like the normative character of knowledge has been contested (Barnes and Bloor, 1982), so can the normative character of ignorance. One could argue that what I have called in this paper practices of ignorance construction are nothing but historical rearrangements of practices of knowledge production, and that my exposing 
of these practices as detrimental to science just follows a lack of historical awareness of the ways in which the human understanding of science and knowledge changes through time.

First, I grant that agnotology presupposes a fundamental distinction between knowledge and ignorance, a distinction that is normative in character, and that still needs important philosophical input (see Fernández Pinto 2015, for some advances in this respect). Second, and after acknowledging that agnotology has this limitation, let me explain the way in which I think the knowledge/ignorance distinction is playing a role in this paper. I have tried to show that the five practices identified here lose their epistemic purpose in favor of some other commercial or industrial purpose, and this is precisely why they stop contributing to the production of knowledge and instead start contributing to the production of ignorance. The search for knowledge is replaced for a search of non-knowledge in two ways: first, because the goal of the practice is no longer knowledge but some commercial interest, and second because the practice has been traditionally associated with the production of knowledge, so that it appears to have an epistemic goal when this is no longer the case, and in this deception it produces further ignorance.

Historians of science and other science scholars have uncovered cases of agnogenesis that seem detrimental to scientific knowledge, i.e., cases which not only impede the proper communication of scientific results, but also affect the way scientific research is done (adjusting the peer review system, shaping lines of research at universities, and fostering a research structure that is industry friendly). As the cases in this paper show, practices of ignorance construction have succeeded in challenging scientific consensus, obscuring scientific knowledge, and fostering confusion among policy makers and the general public. Understanding these practices and the epistemological and social consequences that they entail is certainly a pressing task for science and technology studies today, and agnotology, despite some of its initial limitations, has opened the door for STS scholars to make important contributions in this respect.

\section{Acknowledgments}

I would like to thank Janet Kourany, Phil Mirowski, Anjan Chakravartty, Don Howard, and Annie Cot, as well as two anonymous reviewers at Science \& Technology Studies for their careful reading of earlier drafts of this article and for their valuable comments and suggestions. I would also like to thank the participants of the Coloquio de la Escuela de Ciencias Humanas at Universidad del Rosario, especially Carlos Cardona and Stefan Pohl, for their thoughtful suggestions, as well as the organizers and participants of the History of Economics Society 2015 Meeting at Michigan State University and the European Society for the History of Economic Thought 2015 Meeting at Universidad Adolfo Ibáñez, where I also received valuable feedback on earlier drafts. Finally, thanks to Gabriel Restrepo, graduate assistant in the Department of Philosophy at Universidad de los Andes, for his valuable help formatting the final draft. 


\section{References}

Antilla L (2005) Climate of Scepticism: US Newspaper Coverage of the Science of Climate Change. Global Environmental Change 15: 338-352.

Austin A (2002) Advancing Accumulation and Managing its Discontents: The U.S. Antienvironmental Countermovement. Sociological Spectrum 22: 71-105.

Balmer B (2012) Secrecy and Science: A Historical Sociology of Biomedical and Chemical Warfare. Burlington, VT: Ashgate Publishing Company.

Barben D (2007) Changing Regimes of Science and Politics: Comparative and Transnational Perspectives for a World in Transition. Science and Public Policy 34: 55-69.

Barnes B and Bloor D (1982) Relativism, Rationalism, and the Sociology of Knowlegde. In: Hollis M and Luke S (eds) Rationality and Relativism. Cambridge, Mass.: MIT Press, pp. 21-47.

Barnes DE, Hanauer P, Slade J, Bero LA and Gantz SA (1995) Environmental Tobacco Smoke: The Brown and Williamson Documents. JAMA 274: 248-253.

Bero LA, Galbraith A, Rennie D (1994) Sponsored Symposia on Environmental Tobacco Smoke. JAMA 271: 612-617.

Berridge V (2006) The Policy Response to the Smoking and Lung Cancer Connection in the 1950s and 1960 s. The Historical Journal 49(4): 1185-1209.

Bok DC (2003) Universities in the Marketplace: The Commercialization of Higher Education. Princeton, N.J.: Princeton University Press.

Boykoff MT and Boykoff JM (2004) Balance as Bias: Global Warming and the US Prestige Press. Global Environmental Change 14: 125-136.

Boykoff MT and Boykoff JM (2007) Climate Change and Journalistic Norms: A Case-Study of US Mass-Media Coverage. Geoforum 38: 1190-1204.

Brandt AM (2012) Inventing Conflicts of Interest: A History of Tobacco Industry Tactics. American Journal of Public Health 102: 63-71.

Brulle RJ, Carmichael J and Jenkins JC (2012) Shifting Public Opinion on Climate Change: An Empirical Assessment of Factors Influencing Concern over Climate Change in the U.S., 2002-2010. Climatic Change 114: 169-188.

Calomiris CW and Wallison PJ (2008) Blame Fannie Mae and Congress for the Credit Mess. Wall Street Journal September 23.

Coriat B and Orsi F (2002) Establishing a New Intellectual Property Rights Regime in the United States: Origins, Content and Problems. Research Policy 31: 1491-1507.

Davies RG, Orme CDL, Olson V, et al. (2006) Human impacts and the globaldistribution of extinction risk. Proceedings of the Royal Society B 273: 2127-2133.

Dertouzos ML (1989) Made in America: Regaining the Productive Edge. Cambridge, Mass: MIT Press.

Drope J and Chapman S (2001) Tobacco Industry Efforts at Discrediting Scientific Knowledge of Environmental Tobacco Smoke: A Review of Internal Industry Documents. Journal of Epidemiology and Community Health 55: 588-594.

Dunlap RE and McCright AM (2010) Climate Change Denial: Sources, Actors, and Strategies. In: Lever-Tracy C (ed) The Routledge International Handbook of Climate Change and Society. New York: Routledge Press.

Environmental Protection Agency (1992) Respiratory Health Effects of Passive Smoking: Lung Cancer and Other Disorders. Office of Health and Environmental Assessment. URL: http://www.epa.gov/smokefree/ pubs/etsfs.htmlz 
Fernández Pinto M (2015) Tensions in Agnotology: Normativity in the Studies of Commercially-Driven Ignorance. Social Studies of Science 45: 294-315.

Financial Crisis Inquiry Commission (2011) Reports and fact Sheets. http://www.fcic.gov/resource/reports. Accessed 05 December 2014.

Fischer F (2009) Democracy and Expertise: Reorienting Policy Inquiry. Oxford; New York: Oxford University Press.

Freudenburg WR and Muselli V (2010) Global Warming Estimates, Media Expectations, and the Asymmetry of Scientific Challenge. Global Environmental Change 20: 483-491.

Galison P (2008) Removing Knowledge: The Logic of Modern Censorship. In: Proctor R and Schiebinger L (eds) Agnotology: The Making and Unmaking of Ignorance. Stanford, Ca: Stanford University Press, 37-54.

Glantz SA (1996) The Cigarette Papers. Berkeley: University of California Press.

Goldstein D and Hall KG (2008) Private Sector Loans, Not Fannie or Freddie, Triggered Crisis. McClatchy Washington Bureau. Posted October 12.

Gore A, Guggenheim D, David L, et al. (2006) An Inconvenient Truth. Hollywood, Calif: Paramount.

Greenberg DS (2001) Science, Money, and Politics: Political Triumph and Ethical Erosion. Chicago: University of Chicago Press.

Greenberg DS (2007) Science for Sale: The Perils, Rewards, and Delusions of Campus Capitalism. Chicago: University of Chicago Press.

Greenpeace (2010) Koch Industries Secretly Funding the Climate Denial Machine.Available at: http://www. greenpeace.org/usa/en/media-center/reports/koch-industries-secretly-fund/ (accessed 5.12.2014).

Hart DM (2001) Antitrust and Technological Innovation in the US: Ideas, Institutions, Decisions, and Impacts, 1890-2000. Research Policy 30: 923-936.

Hilts PJ (1996) Smokescreen: The Truth behind the Tobacco Industry Cover-up. Reading, Mass: Addison-Wesley Pub. Co.

Hirayama T (1981) Non-Smoking Wives of Heavy Smokers Have a Higher Risk of Lung Cancer: A Study from Japan. British Medical Journal 282: 183-185.

Hunt R (1999) Patent Reform: A Mixed Blessing for the U.S. Economy? Business Review November/December, $15-29$.

Intergovernmental Panel on Climate Change (1995) Climate Change 1995: IPCC Second Assessment: A Report of the Intergovernmental Panel on Climate Change [S.I.]: Intergovernmental Panel on climate Change.

Jacques PJ, Dunlap RE and Freeman M (2008) The Organisation of Denial: Conservative Think Tanks and Environmental Skepticism. Environmental Politics 17: 349-385.

Kluger R (1996) Ashes to Ashes: America's Hundred-Year Cigarette War, the Public Health, and the Unabashed Triumph of Philip Morris. New York: Alfred A. Knopf.

Krugman P (2008) Fannie, Freddie, and You. New York Times, July 14.

Krugman P (2009) How Did Economists Get It So Wrong? New York Times, September 6.

Kuchinskaya O (2014) The Politics of Invisibility: Public Knowledge about Radiation Health Effects after Chernobyl. Cambridge, MA: MIT Press.

Landau RL (ed) (1973) Regulating New Drugs. Chicago, IL: University of Chicago Center for Policy Studies.

Lave R, Mirowski P and Randalls S (2010) Introduction: STS and neoliberal science. Social Studies of Science 40(5): 659-675. 
Little CC (1959) TIRC Research Program. July 16. Memorandum addressed to T. V. Hartnett. Bates 105615204105615208.

Luntz F (2003) The Environment: A Cleaner, Safer, Healthier America. Memo to the Republican Party, The Luntz Research Companies.

McCright AM and Dunlap RE (2000) Challenging Global Warming as a Social Problem. Social Problems 47: 499-522.

McCright AM and Dunlap RE (2002) Defeating Kyoto: The Conservative Movement's Impact on U.S. Climate Change Policy. Social Problems 50: 348-373.

McCright AM and Dunlap RE (2011) The Politicization of Climate Change and Polarization in the American Public's Views of Global Warming, 2001-2010. The Sociological Quarterly 52: 155-194.

McGarity TO and Wagner WE (2008) Bending Science. Cambridge, Mass: Harvard University Press.

McGoey L (2009) Pharmaceutical Controversies and the Performative Value of Uncertainty. Science as Culture 18: $151-164$.

Michaels D (2008) Doubt is Their Product: How Industry's Assault on Science Threatens Your Health. Oxford: Oxford University Press.

Min D (2011) Faulty Conclusions Based on Shoddy Foundations. Report from the Center for American Progress.

Mirowski P (2011) Science-Mart: Privatizing American Science. Cambridge, Mass.: Harvard University Press.

Mirowski P (2013) Never Let a Serious Crisis Go To Waste: How Neoliberalism Survived the Financial Meltdown. London and New York: Verso.

Mirowski P and Nik-Khah E (2013) Private Intellectuals and Public Perplexity: The Economics Profession and the Economic Crisis. History of Political Economy 45(annual suppl.): 279-311.

Mirowski P and Sent EM (2008) The Commercialization of Science and the Response of STS. In: Hackett EJ, Amsterdamska O, Lynch ME and Wajcman J (eds) The Handbook of Science and Technology Studies. Cambridge, Mass.: MIT Press, pp.635-689.

Muggli ME, Hurt RD and Blanke DD (2003) Science for Hire: A Tobacco Industry Strategy to Influence Public Opinion on Secondhand Smoke. Nicotine \& Tobacco Research 5: 303-314.

National Research Council (1983) Changing Climate: Report of the Carbon Dioxide Assessment Committee. Washington, D.C.: National Academy Press.

New York Times (2012) No Crime, No Punishment. Editorial, August, 25. Available at: http://www.nytimes. com/2012/08/26/opinion/sunday/no-crime-no-punishment.html?_r=0 (accessed 9.3.2017)

Nik-Khah E (2014) Neoliberal Pharmaceutical Science and the Chicago School of Economics. Social Studies of Science 44: 489-517.

Nocera J (2011) An Inconvenient Truth. New York Times, December 19.

Ong E and Glantz SA (2000) Hirayama's Work Has Stood the Test of Time. Bulletin of the World Health Organization 78(7): 938-939.

Oreskes N and Conway EM (2010) Merchants of Doubt: How a Handful of Scientists Obscured the Truth on Issues from Tobacco Smoke to Global Warming. New York: Bloomsbury Press.

Ochsner A (1954) Smoking and Cancer: A Doctor's Report. New York, NY: Julian Messner.

Parascandola M (2005) Science, Industry, and Tobacco Harm Reduction: A Case Study of Tobacco Industry's Scientists Involvement in the National Cancer Institute's Smoking Health Program, 1964-1980. Public Health Reports 120: 338-349.

Perrow C (2010) Organisations and Global Warming. In: Lever-Tracy C (ed) The Routledge International Handbook of Climate Change and Society. New York: Routledge Press, pp.59-77. 
Pinto EJ (2010) Government Housing Policies in the Lead-Up to the Financial Crisis: A Forensic Study, Available at: http://www.aei.org/paper/economics/financial-services/housing-finance/governmenthousing-policies-in-the-lead-up-to-the-financial-crisis-a-forensic-study/ (accessed 5.12.2014).

Proctor R (1988) Racial Hygiene: Medicine under the Nazis. Cambridge, Mass.: Harvard University Press.

Proctor R (1995) Cancer Wars: How Politics Shapes What We Know and Don't Know about Cancer. New York: Basic Books.

Proctor R (1999) The Nazi War on Cancer. Princeton, N.J.: Princeton University Press.

Proctor R (2008) Agnotology: A Missing Term to Describe the Cultural Production of Ignorance (and Its Study). In: Proctor R and Schiebinger L (eds) Agnotology: The Making and Unmaking of Ignorance. Stanford, Ca: Stanford University Press, pp.1-33.

Proctor R (2012) Golden Holocaust: Origins of the Cigarette Catastrophe and the Case for Abolition. Berkeley: University of California Press.

Radder H (2010) The Commodification of Academic Research: Science and the Modern University. Pittsburgh, PA: University of Pittsburgh University Press.

Rajan R (2010) Fault Lines: How Hidden Fractures Still Threaten the World Economy. Princeton: Princeton University Press.

Rappert B (2012) States of Ignorance: The Unmaking and Remaking of Death Tolls. Economy and Society 41: $42-63$.

Resnick DB (2007) The Price of Truth: How Money Affects the Norms of Science. New York: Oxford University Press.

Sismondo S (2009) Ghosts in the Machine: Publication Planning in the Medical Sciences. Social Studies of Science 39: 171-196.

Slaughter S and Rhoades G (1996) The Emergence of a Competitiveness Research and Development Policy Coalition and the Commercialization of Academic Science and Technology. Science, Technology and Human Value 21(3): 303-339.

Slaughter S and Rhoades G (2004) Academic Capitalism and the New Economy: Markets, State, and Higher Education. Baltimore, MD: The Johns Hopkins University Press.

Smith R (2003) Medical Journals and Pharmaceutical Companies. BMJ 326: 1202-1205.

Smithson M (1989) Ignorance and Uncertainty: Emerging Paradigms. New York: Springer.

Tyson LD (1992) Who's Bashing Whom? Trade Conflict in High-Technology Industries. Washington, DC: Institute for International Economics.

Union of Concerned Scientists (2007) Smoke, Mirrors and Hot Air. Available at: http://www.ucsusa.org/ global_warming/solutions/fight-misinformation/exxonmobil-report-smoke.html (accessed 5.12.2014).

Weber EU and Stern PC (2011) Public Understanding of Climate Change in the United States. American Psychologist 66: 315-328.

Wise N (2006) Thoughts on the Politicization of Science through Commercialization. Social Research 73: 1253-1272.

Wynder G, Graham EA and Croninger AB (1953) Experimental Production of Carcinoma. Cancer Research 13: 855-864. 


\section{Notes}

1 The neologism comes from the Greek agnosia, meaning "a state of ignorance or not knowing," and it was originally coined by Proctor with the help of linguist lain Boal in the spring of 1992 (Proctor, 2008: 27-28). Later on, Proctor and Schiebinger edited the programmatic volume Agnotology: The Making and Unmaking of Ignorance (2008), where they introduced the new terrain of agnotology to the academic audience. The volume emerged from two workshops, one held at Pennsylvania State University in April 2003 and another one held at Stanford University in October 2005. For a list of the participants to both workshops, see: http://www.bshs.org.uk/agnatology-the-cultural-production-of-ignorance (accessed 04/08/16) and http://www.stanford.edu/dept/HPS/AgnotologyConference.html (accessed 04/08/16).

2 The U.S. tobacco industry's campaign against scientific research linking tobacco smoking to lung cancer has been documented by a number of scholars and science journalists (See, for example, Glantz, 1996; Hilts, 1996; Kluger, 1996; Parascandola, 2005). For a comparison with the UK tobacco industry case, see Berridge (2006).

3 MacGarity and Wagner (2008) provide a much longer list of agnotological strategies, highlighting the need for a deep change in the legal system regarding science policy issues. Although their focus is not on tobacco, their taxonomy corresponds in many cases to the tobacco strategy. My aim here is to synthesize further the core mechanisms of the tobacco strategy.

4 You can find it at www.exxonsecrets.org (accessed 04/08/16).

5 Frank Luntz worked for the Republican Party during the Bush administration, and is famous for suggesting the use of "climate change" instead of "global warming" in public policy communications to downplay the severity of the issue.

6 Notice the similarity to the tobacco industry's creation of the TIRC.

7 Big Pharma has also innovated in its use of science as PR. Going beyond the tobacco strategy, and taking advantage of their success in the current regime of privatized science, pharmaceutical companies extend their control of the peer review system, not only through ghostwriting and publication-planning strategies (Sismondo, 2009), but also through massive funding of medical journals through advertisement, purchase of reprints, and publishing supplements. But it doesn't stop there. Big Pharma's use of PR has achieved new levels with their use of "seeding trials." These are scientifically meaningless trials conducted with the unique goal of increasing drug prescriptions (Smith, 2003). Doctors get paid important sums of money just to get patients into the "trial," without leading to any scientific advancement.

8 Notice the similarity with Nierenberg's effort to discredit the 1983 NAS report. The government's effort to investigate the underlying causes of the crisis was truncated by partisan interests that further contributed to the confusion regarding who was responsible for the collapse. 